\title{
Analysis of GABRB3 Protein Level After Administration of Valerian Extract (Valeriana officinalis) in BALB/c mice
}

\author{
Erwin Mulyawan ${ }^{1, *}$, Muhammad Ramli Ahmad ${ }^{2}$, Andi Asadul Islam ${ }^{3}$, Muh. Nasrum Massi ${ }^{4}$, Mochammad Hatta ${ }^{4}$, \\ Syafri Kamsul Arif ${ }^{2}$
}

Erwin Mulyawan ${ }^{1, *}$, Muhammad Ramli Ahmad², Andi Asadul Islam $^{3}$, Muh. Nasrum Massi' ${ }^{4}$, Mochammad Hatta ${ }^{4}$, Syafri Kamsul Arif ${ }^{2}$

'Department of Anesthesiology, Faculty of Medicine, Pelita Harapan University, INDONESIA.

${ }^{2}$ Department of Anesthesiology, Intensive Care and Pain Management, Faculty of Medicine, Hasanuddin University, INDONESIA.

${ }^{3}$ Department of Neurosurgery, Faculty of Medicine, Hasanuddin University, INDONESIA.

${ }^{4}$ Department of Molecular Biology and Immunology, Faculty of Medicine, Hasanuddin University, INDONESIA.

\section{Correspondence}

\section{Erwin Mulyawan}

Department of Anesthesiology, Faculty of Medicine, Pelita Harapan University, INDONESIA.

E-mail: erwin_mulys@yahoo.co.id ORCID ID : 0000-0002-3575-7324 History

- Submission Date: 06-04-2020;

- Review completed: 13-04-2020;

- Accepted Date: 15-04-2020;

DOI : 10.5530/pj.2020.12.118

Article Available online http://www.phcogj.com/v12/i4

\section{Copyright}

(C) 2020 Phcogj.Com. This is an openaccess article distributed under the terms of the Creative Commons Attribution 4.0 International license.

\section{ABSTRACT}

Background: Valeriana officinalis is most commonly used as traditional medicine. Valerenic acid is the primary component of Valerian officinalis which inhibits the catabolism of enzyme induced breakdown of gamma amino butyric acid (GABA) in the brain, resulting in sedation. The aim of this study is to determine the level of GABRB3 protein, as part of major inhibitory neurotransmitter in the brain, after administration of Valerian extracts in BALB/c mice. Material and Methods: This is an experimental study using animal model with post test-only controlled group design. Twenty healthy adult male BALB/c mice were randomly divided into four groups, negative control group (Aquadest), positive control group (Diazepam $0.025 \mathrm{mg} / 10 \mathrm{~g}$ ), first treatment group (Valerian extract $2.5 \mathrm{mg} / 10 \mathrm{~g}$ ) and second treatment group (Valerian extract $5 \mathrm{mg} / 10 \mathrm{~g}$ ). The drugs were administered via gastric gavage for seven consecutive days. The blood was drawn from each mice on the first day (before treatment) and on the seventh day of experiment ( 2 hours after treatment). The blood sample was examined by enzyme-linked immunosorbent assay (ELISA) to determine the GABRB3 protein level. Results: GABRB3 protein level in BALB/c mice after administration of Valerian extract was increased significantly in both treatment group $(p<0.0001)$. The highest increment in protein levels was found in the first treatment group with an increase of $2.988 \mu \mathrm{mol} / \mathrm{L}$, compared with the second treatment group with an increase of $2.146 \mu \mathrm{mol} / \mathrm{L}$. Conclusion: GABRB3 protein level in BALB/c mice were increased after administration of Valerian extract. Administration of higher dose does not yield in higher GABRB3 protein level nor sedative effect.

Key words: Valerian extract, Diazepam, GABRB3 protein, BALB/c mice.

\section{INTRODUCTION}

Valerian, also known as Setwall, Valerianae radix, $\mathrm{Phu}$ belongs to Valerianaceae family. It is an herbaceous plant from Europe and Asian, present in almost all countries. The Valerian's root is often used as herbal medicine. Valeriana officinalis is most commonly used as traditional medicine for 2000 years. Since $16^{\text {th }}$ century until now, Valerian extracts has anxiolytic, hypnotic, tranquilizing, and sleep inducing effects that have been demonstrated in both animal studies and clinical trials. Valerian contains volatile oil (menoterpene bornyl acetate, sesquiterpenes, valerinic acid), valepotriates, hidroxy pinoresinol, alkaloid (actinidin, catinidin, valerianin, valerin), and glutamine. Glutamine cross the blood brain barrier which will then be converted into GABA inside GABA-nergic neurons. The primary component of Valerian officinalis is Valerenic acid with hydroxyl and acetone group derivatives, which inhibits catabolism enzyme induced breakdown of gamma amino butyric acid (GABA) in the brain resulting in sedation. ${ }^{1-6}$

Gamma aminobutyric acid receptors are the target of GABA neurotransmitter. Gamma aminobutyric acid is a major inhibitory neurotransmitter that works in the central nervous system. GABA has an important role to reduce the excitation of neurons by inhibiting the transmission of nerve impulses in the brain and also plays a role in the regulation of muscle tone. GABA has two types of receptors located in post synapse neurons, $\mathrm{GABA}_{\mathrm{A}}$ and $\mathrm{GABA}_{\mathrm{B}}$ receptors. $G_{A B A}$ is a pentametric protein consisting of different subunits. The effects of Valerian to induce sleep are associated with $G_{A B A}$ receptors. $G_{A B A}$ receptors are important targets for hypnotic-sedative components, general anesthesia, mechanism of benzodiazepine and barbiturates drugs. $\mathrm{GABA}_{\mathrm{A}}$ receptors are expressed in anatomical regions that involve sleep. The component of Valerian extract has an influence on the $\mathrm{GABA}_{\mathrm{A}}$ receptor (gammaaminobutyric acid subtype A). Valerian influences the presynaptic component of GABA-ergic neurons that affect the release of GABA synaptomals. In addition, Valerian also inhibits GABA reuptake and inhibits GABA catabolism by inhibiting the enzyme GABA transaminase. ${ }^{7-16}$

The mechanism of action of Valerian is similar to Benzodiazepine. Benzodiazepines bind to GABA receptor Gamma subunit (Figure 1). Valerian and Benzodiazepine works on the same GABA receptor but binds to a different subunit, Valerian binds to Beta subunit (Figure 2). Both of them cause the movement of chloride into the neuron when neurotransmitter GABA binds to $\mathrm{GABA}_{\mathrm{A}}$ receptor which generates a chlorine inlet current, which induces a hyperpolarization of the cell membrane and therefore inhibits nerve impulse conduction, so 


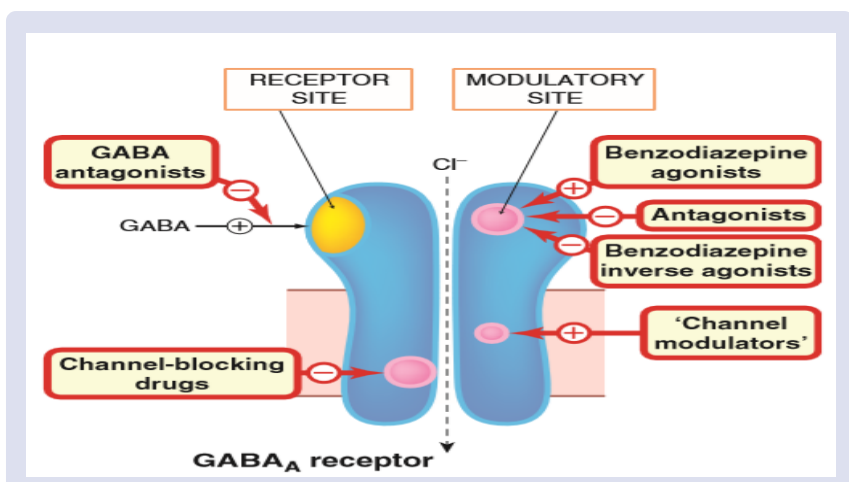

Figure 1: Place of Benzodiazepine Bonding of $\mathrm{GABA}_{\mathrm{A}}$ Receptors. $^{17}$

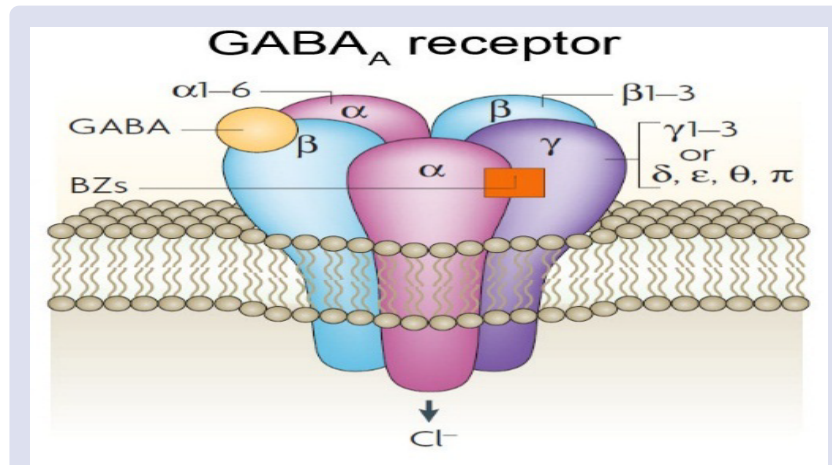

Figure 2: Place of Valerian Bonding of $G A B A_{A}$ Receptors Subunit $\beta .^{18}$

excitatory postsynaptic potentials (EPSPs) make neuron less responsive to stimulation that can suppress central nerve system. Valerian has been shown to reduce metabolism of GABA, thus GABA can last longer. Diazepam has been proved to works on GABA receptor. In this study Diazepam was administered in the positive control group. Diazepam is a GABA agonist that binds specifically to Benzodiazepine receptor of GABA which result in inhibition of central nervous system activity. ${ }^{17-23}$

GABRB3 is a heteromeric gene that encodes the GABA $A_{A}$ receptor $\beta_{3}$ subunit, GABRB3 is a member of the GABA receptor family gene which has a heterometric structure of pentameric ion channel ligand channels where it works from GABA. GABA ${ }_{A}$ receptors are the major inhibitory transmitter receptors in the brain and the site of action of a variety of pharmacologically and clinically important drugs. ${ }^{24-26}$

In 2014, Kakehashi was chosen Valerian extract dose based on previous research that engaged human as a subject. Toxicity effect was not detected even at $500 \mathrm{mg} / \mathrm{kg} /$ day. The dose of 5,50 and $500 \mathrm{mg} / \mathrm{kg} /$ day of Valerian extract with $20 \mathrm{ml}$ of Aquadest has been consumed by the rat (200 g). The conversion factor was used to equated doses from human to rat by multiplying of 6.16 . In this case, animal doses of 5,50 and 500 $\mathrm{mg} / \mathrm{kg}$ was become $0.8,8.1$ and $81.2 \mathrm{mg} / \mathrm{kg}$ on human dose. ${ }^{27}$

According to Al Majeed, doses of Valerian officinalis was determined by three factors such as maximum tolerated dose, body surface area and previous research that has been done. The maximum tolerated dose of 500,1000 , and $2000 \mathrm{mg} / \mathrm{kg}$ was used for mice on the average weight of 20 grams. According to body surface area rules that dose of $397.8 \mathrm{mg} /$ $\mathrm{kg}$ was used because the ratio of $20 \mathrm{~g}$ mice resembling to $60 \mathrm{~kg}$ human. Daily dose of $3060 \mathrm{mg}$ was recommended for human consumption. Gutierrez (2004) concluded from various research that single dose of $1800 \mathrm{mg}$ Valerian extract will induce sedative effect and improve quality of after $1-2$ weeks of ingestion. In this study Valerian extract was given in form of aqueous suspension with gastric gavage for 7 consecutive days. The Diazepam dose of $0.2 \mathrm{mg} / \mathrm{kg}$ is usually used to reduce anxiety and provoke effects of sedation. FDA regulated the doses from human to mice (average weight $20 \mathrm{~g}$ ) by multiplying 12.3 as a conversion factor that make $2.5 \mathrm{mg} / 10 \mathrm{~g}$ and $5 \mathrm{mg} / 10 \mathrm{~g}$ as a meticulous doses. ${ }^{28-30}$

The aim of this study is to determine the level of GABRB3 protein, as part of major inhibitory neurotransmitter in the central nervous system, after administration of Valerian extracts in $\mathrm{BALB} / \mathrm{c}$ mice.

\section{MATERIAL AND METHODS}

This is an experimental study using 20 healthy adult males BALB/c mice, 8-weeks-old, and weighted approximately 25-35 g (Figure 3). Mice that died or pregnant were dropped out of the study. Mice were obtained from the maintenance and development unit of the experimental animal laboratory of Molecular Biology Faculty of Medicine, Hasanuddin University, Makassar, Indonesia. All experimental protocols employed in this study were approved by the Medical Research Ethics Committee of Hasanuddin University Makassar, Indonesia (903/H4.8.4.5.31/PP36KOMTEK/2017).

This study used BALB/c mice since it has the characteristics of easy breeding and minimal weight variations between males and females. Therefore, it is the one of the most extensively used strain in experimental studies, particularly in neurobiology or neuroscience research. BALB/c mice were also used in our reference study regarding the use of Valerian extract. ${ }^{31,32}$ Valerian extract used in this study was Blackmores Valerian Forte, a standardized herbal pill equivalent to 2 gr (2000 mg) of Valeriana officinalis' dry root or rhizome. The extract was diluted with Aquadest to $2 \mathrm{mg} / 0.1 \mathrm{ml}$ solution. The drugs were administered via gastric gavage with $1 \mathrm{ml}$ syringe (Figure 4).

The mice were adapted for one week in a room with room temperature of $25{ }^{\circ} \mathrm{C}, 12$-hour cycle of light and dark, and were given proper food and drink. Before drug administration, all mice were fasted for 3 hours. The mice were divided into 4 groups, as follows: negative control group with Aquadest $5 \mathrm{ml}$; control positive group with Diazepam $0.025 \mathrm{mg} / 10$ g; first treatment group with Valerian extract $2.5 \mathrm{mg} / 10 \mathrm{~g}$; second treatment group with Valerian extract $5 \mathrm{mg} / 10 \mathrm{~g}$. In this study, the dose of Valerian extract was adjusted from the human daily dose of 20 $\mathrm{mg} / \mathrm{kg}$ and $40 \mathrm{mg} / \mathrm{kg}$. The maximum tolerated dose in human are 81.2 $\mathrm{mg} / \mathrm{kg}$ according to Kakehashi (2014), and $51 \mathrm{mg} / \mathrm{kg}$ according to $\mathrm{Al}$ Majeed (2006). Food and Drugs Administration (FDA) regulated the doses from human to mice by multiplying 12.3 as a conversion factor, which led to the final dose of $2,5 \mathrm{mg} / 10 \mathrm{~g}$ and $5 \mathrm{mg} / 10 \mathrm{~g}$ as a meticulous doses for mice on the average weight of 20 grams. Meanwhile, the dose of Diazepam was adjusted from human daily dose of $0.2 \mathrm{mg} / \mathrm{kg}$, multiplied by 12.3 as a conversion factor, which led to the final dose of $2.5 \mathrm{mg} / \mathrm{kg}$ or $0.025 \mathrm{mg} / 10$ g. $^{27,28}$

The blood was drawn from each mice on the first day (before treatment) and on the seventh day of experiment ( 2 hours after treatment), as showed as in figure 5 . The blood sample was examined by enzymelinked immunosorbent assay (ELISA) Reader 270 (Biomeriux, France) to determine the GABRB3 protein level.

The data were analyzed using SPSS software version 20 . The data were tested with Shapiro-Wilks test. The statistical analysis technique using ANOVA test was used to compare numerical difference in each group. Paired T-test and Independent T-test was used to compare the GABRB3 protein level of each group, before and after experiment. $\mathrm{P}$ value $<0.05$ was considered significant.

\section{RESULTS}

Table 1 showed the comparison of GABRB3 protein levels between before and after treatment from all group using statistical analysis Paired T-test. There was a significant increment of GABRB3 protein level from $2.366 \mu \mathrm{mol} / \mathrm{L}$ before treatment to $3.118 \mu \mathrm{mol} / \mathrm{L}$ after treatment $(p<0.0001)$. 


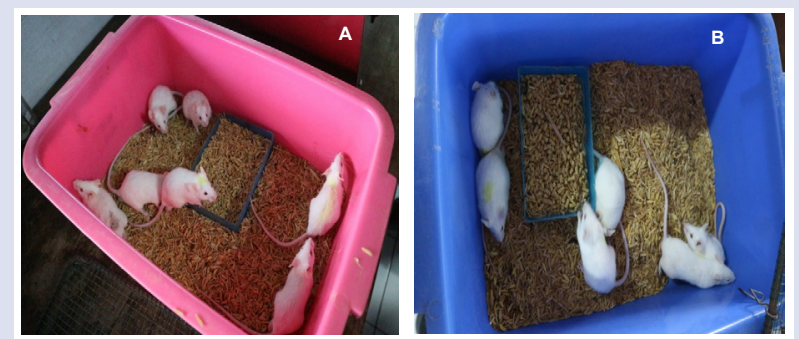

Figure 3: $B A L B / C$ mice used in this study. (a) $B A L B / c$ mice Before Grouping (b) BALB/c mice After Grouping B.

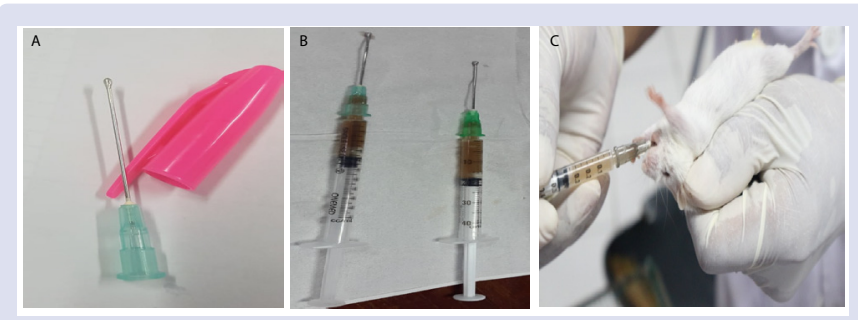

Figure 4: Administration of diluted valerian extract by using gastric gavage with $1 \mathrm{ml}$ syringe (a) gastric gagave (b) $1 \mathrm{ml}$ syringe with Valerian extract (c) administration Valerian extract to BALB/C mice.

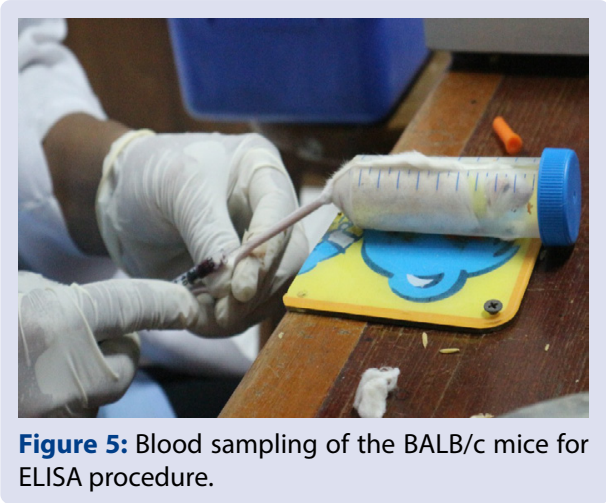

Table 2 showed the comparison of GABRB3 protein levels between before and after treatment from each group using Paired T-test statistical analysis. In the negative control group, there was an increment of protein level from $2.048 \mu \mathrm{mol} / \mathrm{L}$ before treatment to $2.299 \mu \mathrm{mol} / \mathrm{L}$ after treatment, although not significant $(p=0.341)$. In the positive control group, there was an almost significant increment of protein level from $1.869 \mu \mathrm{mol} / \mathrm{L}$ before treatment to $2.849 \mu \mathrm{mol} / \mathrm{L}$ after treatment $(\mathrm{p}=0.067)$. In the first treatment group (Valerian 2.5 $\mathrm{mg} / 10 \mathrm{~g})$, there was a significant increment of protein level $(\mathrm{p}<0.0001)$ from $2.371 \mu \mathrm{mol} / \mathrm{L}$ before treatment to $5.359 \mu \mathrm{mol} / \mathrm{L}$ after treatment. In the second treatment group (Valerian $5 \mathrm{mg} / 10 \mathrm{~g}$ ), there was also a significant increment of protein level $(p<0.0001)$ from $2.102 \mu \mathrm{mol} / \mathrm{L}$ before treatment to $4.248 \mu \mathrm{mol} / \mathrm{L}$ after treatment.

Statistical analysis using ANOVA test in the four groups (Table 3) showed that the average value of GABRB3 protein levels before treatment did not show a significant difference between each group $(p=$ $0,67)$, while the contrary was found after treatment $(p<0.0001)$.

Table 4 and 5 showed the comparison of GABRB3 protein levels between two groups. There were no significant differences $(p>0.05)$ in GABRB3 protein level before treatment. However, there were significant differences in GABRB3 protein level between two groups after treatment $(p<0.05)$, as shown as in Table 5. Among the comparison between 2 groups, the most significant differences in GABRB3 protein levels was found between the negative control group (Aquadest) and first treatment group (Valerian $2.5 \mathrm{mg} / 10 \mathrm{~g}$ ), between the negative control group (Aquadest) and second treatment group (Valerian $5 \mathrm{mg} / 10 \mathrm{gr}$ ), and between the positive control group (Diazepam) and first treatment group (Valerian $2.5 \mathrm{mg} / 10 \mathrm{~g}$ ) with $p$ value $<0.0001$.

\section{DISCUSSION}

The majority of the world's population still uses natural herbal medicines, and Valerian is one of the herbal medicines that is often used. The Valerian cellular target is the $\mathrm{GABA}_{\mathrm{A}}$ receptor (sub-unit $\beta 3$ ) which is linked to the GABRB3 gene to cause sedation effects. The aim of this study is to evaluate the connection between Valerian extract and increment of GABRB3 protein level to induce sedation effect.

Tabel 1: Comparison Between GABRB3 Protein Level Before and After Treatment of All Groups

\begin{tabular}{cccccccc}
\hline Variable & N & $\begin{array}{c}\text { Mean } \\
(\mu \mathrm{mol} / \mathrm{L})\end{array}$ & SD & Min & Max & Median & P value \\
\hline GABRB3 Protein Level (Before Treatment) & 20 & 2.098 & 0.551 & 0.947 & 2.646 & 2.366 & $<0.0001$ \\
GABRB3 Protein Level (After Treatment) & 20 & 3.689 & 1.281 & 2.025 & 5.468 & 3.118 & $<$ \\
\hline
\end{tabular}

Data were analyzed with Paired $t$-test, $P$-value of $<0.05$ was considered significant.

Tabel 2: Comparison Between GABRB3 Protein Level Before and After Treatment of Each Group

\begin{tabular}{|c|c|c|c|c|c|c|c|c|}
\hline Group & Variable & $\mathrm{N}$ & Mean $(\mu \mathrm{mol} / \mathrm{L})$ & SD & Min & Max & Median & $P$ value \\
\hline & Aquadest $5 \mathrm{ml}$ Group & & & & & & & \\
\hline \multirow[t]{2}{*}{ I } & Before Treatment & 5 & 2.048 & 0.409 & 1,579 & 2.493 & 1.933 & \multirow{2}{*}{0.341} \\
\hline & After Treatment & 5 & 2.299 & 0.209 & 2,025 & 2.554 & 2.364 & \\
\hline \multirow{4}{*}{ II } & Diazepam $0.025 \mathrm{mg} / 10 \mathrm{~g} \mathrm{Gr}$ & up & & & & & & \\
\hline & Before Treatment & 5 & 1.869 & 0.817 & 0.947 & 2.623 & 2.284 & \multirow{2}{*}{0.067} \\
\hline & After Treatment & 5 & 2.849 & 0.152 & 2.71 & 3.046 & 2.783 & \\
\hline & Valerian $2.5 \mathrm{mg} / 10 \mathrm{~g}$ Group & & & & & & & \\
\hline \multirow[t]{2}{*}{ III } & Before Treatment & 5 & 2.371 & 0.317 & 1.846 & 2.646 & 2.421 & \multirow{2}{*}{$<0,0001$} \\
\hline & After Treatment & 5 & 5.359 & 0.1 & 5.198 & 5.468 & 5.377 & \\
\hline \multirow{3}{*}{ IV } & Valerian $5 \mathrm{mg} / 10 \mathrm{~g}$ Group & & & & & & & \\
\hline & Before Treatment & 5 & 2.102 & 0.588 & 1.088 & 2.508 & 2.379 & \multirow{2}{*}{$<0.0001$} \\
\hline & After Treatment & 5 & 4.248 & 0.738 & 3.190 & 4.973 & 4.527 & \\
\hline
\end{tabular}

Data were analyzed with Paired $t$-test, $P$-value of $<0.05$ was considered significant. 
Table 3: Comparison Between GABRB3 Protein Level Before and After Treatment of Four Groups

\begin{tabular}{|c|c|c|c|c|c|c|c|}
\hline No & Variable & $\mathrm{N}$ & $\begin{array}{c}\text { Mean } \\
(\mu \mathrm{mol} / \mathrm{L}) \\
\end{array}$ & SD & Median & $P$ value & F value \\
\hline \multirow[t]{5}{*}{1.} & GABRB3 Protein Level Before Treatment & & & & & \multirow{5}{*}{0.582} & \multirow{5}{*}{0.67} \\
\hline & Aquadest $5 \mathrm{ml}$ & 5 & 2.048 & 0.409 & 1.933 & & \\
\hline & Diazepam $0.025 \mathrm{mg} / 10 \mathrm{~g}$ & 5 & 1.869 & 0.817 & 2.284 & & \\
\hline & Valerian $2.5 \mathrm{mg} / 10 \mathrm{~g}$ & 5 & 2.371 & 0.317 & 2.421 & & \\
\hline & Valerian $5 \mathrm{mg} / 10 \mathrm{~g}$ & 5 & 2.102 & 0.588 & 2.379 & & \\
\hline \multirow[t]{5}{*}{2.} & GABRB3 Protein Level After Treatment & & & & & & \\
\hline & Aquadest $5 \mathrm{ml}$ & 5 & 2.299 & 0.209 & 2.364 & \multirow{4}{*}{$<0.0001$} & \multirow{4}{*}{61.49} \\
\hline & Diazepam $0.025 \mathrm{mg} / 10 \mathrm{~g}$ & 5 & 2.849 & 0.152 & 2.783 & & \\
\hline & Valerian $2.5 \mathrm{mg} / 10 \mathrm{~g}$ & 5 & 5.359 & 0.1 & 5.377 & & \\
\hline & Valerian $5 \mathrm{mg} / 10 \mathrm{~g}$ & 5 & 4.248 & 0.738 & 4.527 & & \\
\hline
\end{tabular}

Data were analyzed with ANOVA test, P-value of $<0.05$ was considered significant.

Table 4: Comparison of GABRB3 Protein Level Before Treatment Between Two Groups

\begin{tabular}{|c|c|c|c|c|c|c|c|}
\hline No & Variable $(n=5)$ & $\begin{array}{c}\text { Mean } \\
(\mu \mathrm{mol} / \mathrm{L})\end{array}$ & SD & Min & Max & Median & $P$ value \\
\hline \multirow{2}{*}{1.} & Aquadest $5 \mathrm{ml}$ & 2.048 & 0.409 & 1.579 & 2.493 & 1.933 & \multirow{2}{*}{0.674} \\
\hline & Diazepam $0.025 \mathrm{mg} / 10 \mathrm{~g}$ & 1.869 & 0.817 & 0.947 & 2.623 & 2.284 & \\
\hline \multirow{2}{*}{2.} & Aquadest $5 \mathrm{ml}$ & 2.048 & 0.409 & 1.579 & 2.493 & 1.933 & \multirow{2}{*}{0.201} \\
\hline & Valerian $2.5 \mathrm{mg} / 10 \mathrm{~g}$ & 2.371 & 0.317 & 1.846 & 2.646 & 2.421 & \\
\hline \multirow{2}{*}{3.} & Aquadest $5 \mathrm{ml}$ & 2.048 & 0.409 & 1.579 & 2.493 & 1.933 & \multirow{2}{*}{0.868} \\
\hline & Valerian $5 \mathrm{mg} / 10 \mathrm{~g}$ & 2.102 & 0.588 & 1.088 & 2.508 & 2.379 & \\
\hline \multirow{2}{*}{4.} & Diazepam $0.025 \mathrm{mg} / 10 \mathrm{~g}$ & 1.869 & 0.817 & 0.947 & 2.623 & 2.284 & \multirow{2}{*}{0.237} \\
\hline & Valerian $2.5 \mathrm{mg} / 10 \mathrm{~g}$ & 2.371 & 0.317 & 1.846 & 2.646 & 2.421 & \\
\hline \multirow{2}{*}{5.} & Diazepam $0.025 \mathrm{mg} / 10 \mathrm{~g}$ & 1.869 & 0.817 & 0.947 & 2.623 & 2.284 & \multirow{2}{*}{0.396} \\
\hline & Valerian $5 \mathrm{mg} / 10 \mathrm{~g}$ & 2.102 & 0.588 & 1.088 & 2.508 & 2.379 & \\
\hline \multirow{2}{*}{6.} & Valerian $2.5 \mathrm{mg} / 10 \mathrm{~g}$ & 2.371 & 0.317 & 1.846 & 2.646 & 2.421 & \multirow{2}{*}{0.619} \\
\hline & Valerian $5 \mathrm{mg} / 10 \mathrm{~g}$ & 2.102 & 0.588 & 1.088 & 2.508 & 2.379 & \\
\hline
\end{tabular}

Data were analyzed with Independent $t$-test, P-value of $<0.05$ was considered significant.

Table 5: Comparison of GABRB3 Protein Levels After Treatment Between Two Groups

\begin{tabular}{|c|c|c|c|c|c|c|c|}
\hline No & Variable $(n=5)$ & $\begin{array}{c}\text { Mean } \\
(\mu \mathrm{mol} / \mathrm{L})\end{array}$ & SD & Min & Max & Median & $P$ value \\
\hline \multirow{2}{*}{1.} & Aquadest $5 \mathrm{ml}$ & 2.299 & 0.209 & 2.025 & 2.554 & 2.364 & \multirow{2}{*}{0.001} \\
\hline & Diazepam $0.025 \mathrm{mg} / 10 \mathrm{~g}$ & 2.849 & 0.152 & 2.710 & 3.045 & 2.783 & \\
\hline \multirow{2}{*}{2.} & Aquadest $5 \mathrm{ml}$ & 2.299 & 0.209 & 2.025 & 2.554 & 2.364 & \multirow{2}{*}{$<0.0001$} \\
\hline & Valerian $2.5 \mathrm{mg} / 10 \mathrm{~g}$ & 5.359 & 0.100 & 5.198 & 5.468 & 5.377 & \\
\hline \multirow{2}{*}{3.} & Aquadest $5 \mathrm{ml}$ & 2.299 & 0.209 & 2.025 & 2.554 & 2.364 & \multirow{2}{*}{$<0.0001$} \\
\hline & Valerian $5 \mathrm{mg} / 10 \mathrm{~g}$ & 4.248 & 0.738 & 3.19 & 4.973 & 4.527 & \\
\hline \multirow{2}{*}{4.} & Diazepam $0.025 \mathrm{mg} / 10 \mathrm{~g}$ & 2.849 & 0.152 & 2.71 & 3.045 & 2.783 & \multirow{2}{*}{$<0.0001$} \\
\hline & Valerian $2.5 \mathrm{mg} / 10 \mathrm{~g}$ & 5.359 & 0.1 & 5.198 & 5.468 & 5.377 & \\
\hline \multirow{2}{*}{5.} & Diazepam $0.025 \mathrm{mg} / 10 \mathrm{~g}$ & 2.849 & 0.152 & 2.71 & 3.045 & 2.783 & \multirow{2}{*}{0.003} \\
\hline & Valerian $5 \mathrm{mg} / 10 \mathrm{~g}$ & 4.248 & 0.738 & 3.19 & 4.973 & 4.527 & \\
\hline \multirow{2}{*}{6.} & Valerian $2.5 \mathrm{mg} / 10 \mathrm{~g}$ & 5.359 & 0.100 & 5.198 & 5.468 & 5.377 & \multirow{2}{*}{0.01} \\
\hline & Valerian $5 \mathrm{mg} / 10 \mathrm{~g}$ & 4.248 & 0.738 & 3.19 & 4.973 & 4.527 & \\
\hline
\end{tabular}

Data were analyzed with Independent $t$-test, $P$-value of $<0.05$ was considered significant.

According to the American Society of Anesthesiologists, sedation is a condition of decreased awareness to the surrounding environment as well as a reaction to external stimuli. ${ }^{28,33,34}$

In this study the GABRB3 protein level in each mice was analyzed two times. The first blood sample was drawn from each mice on the first day, precisely before drug administration. The second blood sample was drawn from each mice on the seventh day of experiment, precisely 2 hours after drug administration. The blood sample was examined by enzyme-linked immunosorbent assay (ELISA) to determine the GABRB3 protein level.

The GABRB3 protein levels in the negative control group (Aquadest 5 $\mathrm{ml}$ ) showed no significant differences with $p$ value of 0.341 , from level of
$2.048 \mu \mathrm{mol} / \mathrm{L}$ before treatment to level of $2.299 \mu \mathrm{mol} / \mathrm{L}$ after treatment. The GABRB3 protein levels in the positive control group (Diazepam $0.025 \mathrm{mg} / 10 \mathrm{~g}$ ) showed an almost significant increment with $p$ value of 0.067 , from level of $1.869 \mu \mathrm{mol} / \mathrm{L}$ before treatment to level of 2.849 $\mu \mathrm{mol} / \mathrm{L}$ after treatment. Although the protein level increment was not significant, the $\mathrm{p}$ value obtained is close 0.05 . This fact is due to the lack of subjects in each group ( 5 mice) and it is expected that increasing the number of subjects will produce a more significant differences.

The GABRB3 protein levels in first treatment group (Valerian $2.5 \mathrm{mg} / 10$ g) showed a significant increment with $p$ value of $<0.0001$, from level of $2.371 \mu \mathrm{mol} / \mathrm{L}$ before treatment to level of $5.359 \mu \mathrm{mol} / \mathrm{L}$ after treatment. The GABRB3 protein level in the second treatment group (Valerian 
$5 \mathrm{mg} / 10 \mathrm{~g}$ ) showed a significant increment with a $p$ value of $<0.0001$, from level of $2.102 \mu \mathrm{mol} / \mathrm{L}$ before treatment to level of $4.248 \mu \mathrm{mol} / \mathrm{L}$ after treatment. The results showed a significant increment of GABRB3 protein levels after administration of Valerian extracts. Thus, this study proved that Valerian extracts are associated with changes in GABRB3 protein levels, as a gene that encodes the GABA receptor beta subunit.

The GABRB3 protein levels after treatment in the four groups showed a significant difference. The protein in the negative control group (Aquadest) was seen to have the lowest level, then followed by a positive control group (Diazepam). The highest GABRB3 protein levels after treatment were obtained in the first treatment group (Valerian $2.5 \mathrm{mg} / 10 \mathrm{~g}$ ) and followed by the second treatment group (Valerian $5 \mathrm{mg} / 10 \mathrm{~g}$ ). The fact showed that the increment of GABRB3 protein level in the first treatment group, with lower dose of Valerian, have resulted in higher increment level compared to the second treatment group, with higher dose of Valerian. Therefore, we can conclude that by increasing the dose of Valerian extract, does not increase the GABRB3 protein level.

This study support by Kniffin (2016), that GABRB3 is a heteromeric gene that encodes the $\mathrm{GABA}_{\mathrm{A}}$ receptor $\beta_{3}$-subunit. The GABRB3 is a member of the GABA receptor family gene which has a heterometric structure of pentameric ion channel ligand channels where it works from GABA. ${ }^{21}$. GABA has an important role to reduce the excitation of neurons by inhibiting the transmission of nerve impulses in the brain. Khom et al. and meta-analysis studies by Bent et al. Khom et al (2016) related to the effect of valeric acid on the GABAA receptor $\beta$ subunit. Valerenic acid inhibits catabolism enzyme induced breakdown of gamma amino butyric acid (GABA) in the brain resulting in sedation..$^{8,19}$ The result also consistent with study from Miftakhul (2009) which Valerian extract can cause sedative effect on BALB/c mice ( $p$ $<0.001$ ) and consistent with Al Majeed (2006) which Valerian liquid suspension can give effect of pili pili erection, hyperthermia, defecation, reflex disturbance and sedation effect. The results obtained in the study indicate that valeric acid can modulate $\mathrm{GABA}_{\mathrm{A}}$ subunit $\beta 3$ receptors and induce a significant effect of sedation on mice. ${ }^{28,35}$

This study has several limitations. First, there are various available formulation of Valerian extract without a clear standard of processing method. Second, this study was not performing a staining of brain slice to determining the GABRB3 protein level through immunohistochemistry tests. Third, this study was not conduct behavioral experiment and needed to better explain the observed processes and mechanisms, responsible for the development sedative effect use beam walking assay and chimney test. More definitive studies to determine the correlation between GABRB3 protein level and sedation effect are needed.

\section{CONCLUSION}

Valerian extract is bound to the GABA receptor subunit- $\beta_{3}$ to induce sedation effect and the GABRB3 protein levels was increased after administration of Valerian Extract in BALB/c mice. Increasing dose of Valerian extract does not increase the GABRB3 protein level that associated to the sedative effect.

\section{ACKNOWLEDGEMENTS}

This study was not sponsored by government or pharmaceutical company fund.

\section{CONFLICTS OF INTEREST}

The authors declare there is no conflict of interest.

\section{REFERENCES}

1. Benke D, Barberis A, et al. 2009.GABA receptors as in vivo substrate for the anxiolytic action of valerenic acid, a major constituent of Valerian root extracts. Neuropharmacology : 174-81.
2. Fernandez S, Wasowski C,et al. 2004. Sedative and sleep-enhancing properties of linarin, a flavonoid-isolated from Valeriana officinalis. Pharmacology Biochemistry and Behaviour : 399-404.

3. National Toxicology Program Chemical Information Review Document for Valerian (Valeriana officinalis L) [CAS No8057-49-6] and Oils [CAS No8008-886]. 2009. New York : U.S Department of Health and Human Services.

4. Leuschner J, Muller J and Rudmann M. 1993. Characterization of the central nervous depressant activity of a commercially available Valerian root extract. Arzneimittelforschung : 638-641.

5. Nazari F, Shaabani S and Nejad Ebrahimi, S. 2009. Investigation of Valeriana officinalis L. from Iran.57 th International Congress and Annual Meeting of the GA. - Geneva, Switzerland. Planta Medica : 75-79.

6. Sundaresan N, Kasthuri B, Kaliappan I. 2018. Valeriana Officinalis: A Review Of Its Traditional Uses, Phytochemistry And Pharmacology. Asian Journal of Pharmaceutical and Clinical Research (11): 36-41.

7. Rafacl A. 2018. The GABAergic System: An Overview of Physiology, Physiopathology and Therapeutics. Int J Clin Pharmacology and Pharmacotherapy (3): 142.

8. Bent S, Padula A, et. al. 2006. Valerian for sleep: A Systematic Review and Meta-analysis. Am J Med 119 (12): 1005 - 1012.

9. Hendriks H, Bos R, et al. Central Nervous Depressant Activity of Valerenic Acid in the Mouse. Planta medica : $28-31$

10. Neuhaus W, TraunerG, et al. 2008. Transport of a GABA A Receptor Modulator and Its Derivatives from Valeriana officinalis L. S. I. Across an in Vitro Cell Culture Model of the Blood-Brain Barrier.Planta Medica: 1338- 1344.

11. Sigel E and Steinmann M. 2012. Structure, Function, and Modulation of GABA Receptor. Journal of Biological Chemistry: 40224-40231.

12. Ernst M, Brauchart D, et al. 2003.Comparative modeling of GABAA receptors: limits, insights, future developments. Neuroscience: 933-943.

13. Miller Paul S. and Aricescu A. Radu. 2014. Crystal structure of a human GABAA receptor. Nature.

14. Rudolph U. 2015. Diversity and functions of GABA receptors : A Tribute to Hanns Möhler, Part A, Volume 72. Academic Press.

15. Schofield P, Darlison M, et al. 1987. Sequence and functional expression of the GABAA receptor shows a ligand-gated receptor super-family. Nature: 221-227.

16. Spitzer N. 2010. How GABA generates depolarization. The Journal of Physiology: 757-758.

17. Rang \& Dale's Pharmacology (edisi ke-7th). Elsevier Churchill Livingstone. 2012.

18. Jacob Tija C., Moss Stephen J. and Jurd Rachel. 2008.GABAA receptor trafficking and its role in the dynamic modulation of neuronal inhibition. Neuroscience : 331-343.

19. Khom S, Baburin I, et al. 2005.Pharmacological Properties of GABAA Receptors Containing $\alpha$ Sub-units. Molecular Pharmacology: 640-649.

20. Budzinski Jason W, Foster $B$, et al. 2000. An in vitro evaluation of human cytochrome P450 3A4 inhibition by selected commercial herbal extracts and tincture. Phytomedicine : 273-282.

21. Kniffin Cassandra L.2016. Gamma-Aminobutyric Acid Receptor Beta 3 GABRB3. OMIM.

22. Chun-Su Yuan, Sangeeta M, et al. 2004. The Gamma-Aminobutyric Acidergic Effects of Valerian and Valerenic Acid on Rat Brainstem Neuronal Activity Anesthesia and Analgesia: 353-8.

23. Nazari F, Shaabani S and Nejad Ebrahimi, S. 2009. Investigation of Valeriana officinalis L. from Iran.57 th International Congress and Annual Meeting of the GA. - Geneva, Switzerland. Planta Medica : 75-79.

24. Papandreou A, Mctague A, Trump N, Ambegaonkar G, Ngoh A, Meyer E, et al. GABRB3 mutations: A new and emerging cause of early infantile epileptic encephalopathy. Dev Med Child Neurol. 2016;58(4):416-20.

25. Richter L, Graaf C De, Sieghart W, Varagic Z, Mörzinger M, Esch IJP De, et al. Diazepam-bound GABAA receptor models identify new benzodiazepine binding-site ligands. Nat Chem Biol. 2012;8(5):455-64.

26. Fukuchi Mamoru and Tsuda Masaaki. 2015. GABA-driven excitatory neurotransmission: gene regulation by excitatory GABA and its possible role in the developing brain. Neurotransmiter: 2: e480

27. Kakeshi A, Kato A, et al. 2014. Valerian Inhibits Rat Hepatocarcinogenesis by Activating GABA(A) Receptor-Mediated Signaling. PLoS ONE 9(11): e113610

28. Al-Majed A, Al-Yahya A, et al. 2006. Studies on Cytological and Bichemical Effects of Valerian in Somatic and Germ Cells of Swiss Albino Mice. Food and Chemical Toxicology 44: 1830-1837.

29. Gutierrez S, Ang-Lee M, et.al. 2004. Assesing Subjective and Psychomotor Effects of the Herbal Medication Valerian in Healthy Volunteers. Pharmacology, Biochemistry and Behavior 78: 57-64

30. Pharmacist Prescribing Task Force. 2009. Prescribing by Pharmacists: Information Paper. CJHP

31. Mary Johnson. 2012. Laboratory Mice and Rats. Mater Methods 2012;2:113 
32. The Jackson Laboratory. Balb/c Mice. https://jax.org/strain/000651

33. American Society of Anesthesiologist. 2004. Continuum of Depth of Sedation: Definition of General Anesthesia and levels of Sedation / Analgesia.
34. Malamed S.2010. Sedation 5th edition. St. Louis: Mosby Elsevier.

35. Miftakhul J. 2009. The Effect of Valerian Extract on Sedative Effect of BALB/C Mice. Falculty of Medicine, Universitas Diponegoro.

\section{GRAPHICAL ABSTRACT}

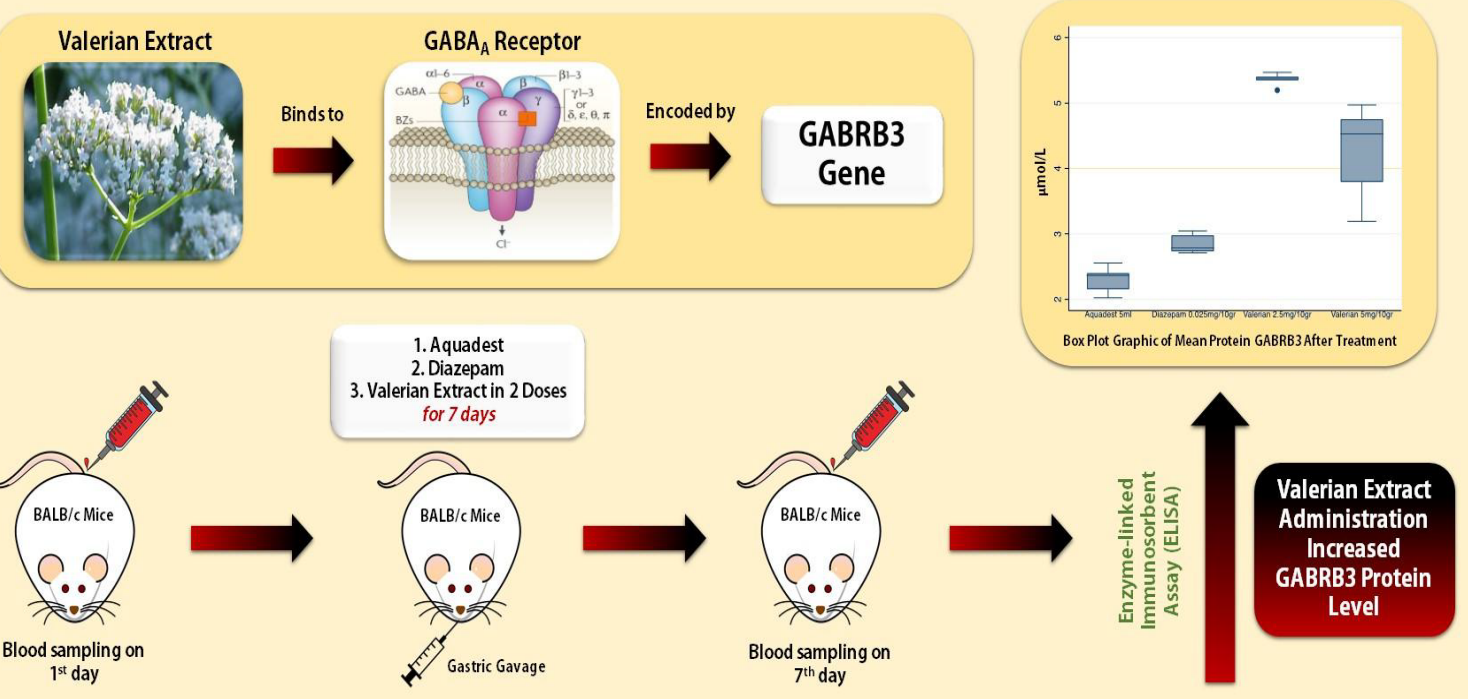

\section{ABOUT AUTHORS}

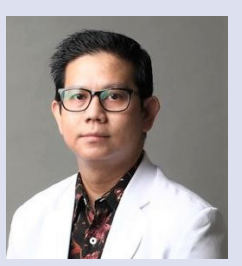

Erwin Mulyawan, MD, Anesthesiologist, Pain Management (Cons) is a Lecturer at Department of Anesthesiology, Faculty of Medicine, Pelita Harapan University and Consultant of Anesthesiology and Pain Management at Siloam Hospitals, Indonesia..

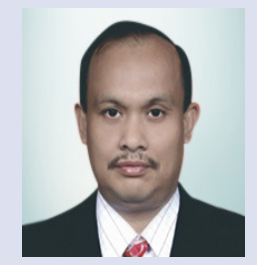

Prof. Muhammad Ramli Ahmad, MD, Ph.D., Pain Management (Cons), Pediatric Anesthesiologist (Cons) is a Professor and Chairman of Department of Anesthesiology, Intensive Care and Pain Management at Medical Faculty of Hasanuddin University, Makassar, Indonesia.

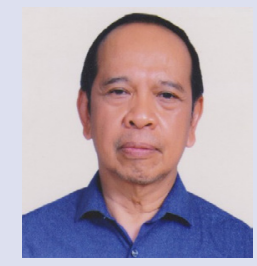

Prof. Andi Asadul Islam, MD, Ph.D., Neurosurgeon (Cons), is a Professor at Department of Neurosurgery and Former Dean of Medical Faculty of Hasanuddin University, Makassar, Indonesia.

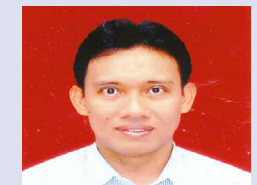

Prof. Muh. Nasrum Massi, MD, Ph.D., Clinical Microbiologist, is a Professor on Molecular Microbiology and Immunology for Infectious Diseases at Medical Faculty of Hasanuddin University and Vice Chancellor of Research, Innovation and Collaboration of Hasanuddin University, Makassar, Indonesia. 


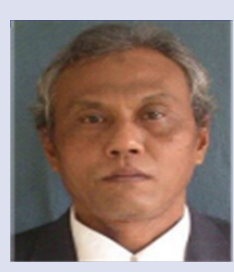

Prof. Mochammad Hatta, MD., Ph.D., Clin. Microbiologist (Cons) is a Professor on Molecular Biology and Immunology for Infectious Diseases from Medical Faculty of Hasanuddin University, Makasssar, Indonesia.

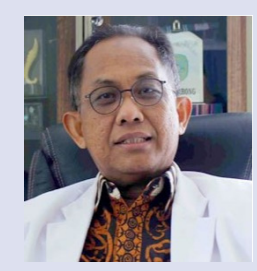

Prof. Syafri Kamsul Arif, MD, Ph.D., Intensive Care Medicine (Cons), Cardiac Anesthesia (Cons) is a Professor at Department of Anesthesiology, Intensive Care and Pain Management at Medical Faculty of Hasanuddin University, Makassar, Indonesia and Chairman of The Indonesian Society of Anesthesiologists and Intensive Therapy.

Cite this article: Mulyawan E, Ahmad MR, Islam AA, Massi MN, Hatta M, Arif SK. Analysis of GABRB3 Protein Level After Administration of Valerian Extract (Valeriana officinalis) in BALB/c Mice. Pharmacogn J. 2020;12(4):821-7. 